\title{
Translation and Cross-Cultural Adaptation into Brazilian Portuguese of the Oxford Ankle Foot Questionnaire (OxAFQ)
}

\section{Tradução e Adaptação Transcultural para o Português Brasileiro do Questionário Oxford Foot and Ankle Questionnaire (OxAFQ)}

Correspondence addresses: Marcos Almeida Matos, MD marcos.almeida@hotmail.com

Received: August 16, 2019

Revised: August 28, 2019

Accepted: September 9, 2019

Published: December 2 $2^{\text {nd }}, 2019$

Data Availability Statement: All relevant data are within the paper and its Supporting Information files.

Funding: This work was the result of authors' initiative. There was no support of research or publication funds.

Competing interests: The authors have declared that no competing interests exist.

\section{Copyright}

(C) 2019 by Santa Casa de Misericórdia da Bahia. All rights reserved. ISSN: 2526-5563

\author{
Marcos Almeida Matos ${ }^{1 *}$, Antero Tavares Neto ${ }^{2}$ \\ ${ }^{1}$ Associate Professor of Escola Bahiana de Medicina e Saúde Pública; Coordinator of the \\ Pediatric Orthopedics Department of Hospital Santa Izabel; ${ }^{2}$ Coordinator of the Foot and \\ Ankle Department of Hospital Santa Izabel; Master Student of Health Technologies at Escola \\ Bahiana de Medicina e Saúde Pública; Salvador, Bahia, Brazil
}

O objetivo do estudo foi realizar a tradução e adaptação transcultural para o português brasileiro do Oxford Foot and Ankle Questionnaire para crianças e adolescentes. Foram seguidas todas as etapas recomendadas internacionalmente para tradução e validação transcultural de instrumentos psicométricos em saúde. Os tradutores foram cinco ortopedistas pediátricos nativos do idioma português e fluentes no inglês; 0 retro tradutor foi um professor de inglês nativo americano com fluência em português; os revisores da retro tradução foram três indivíduos nativos americanos sem expertise na área de saúde e sem fluência em português; o consultor foi um indivíduo versado em tradução e validação de instrumentos psicométricos nativo do português e fluente no inglês. Estes indivíduos foram responsáveis pela tradução e retro tradução do questionário cujas versões foram confrontadas com o original em língua inglesa. Para adaptação transcultural foram utilizadas dez pais e crianças com pés planos flexíveis. A versão final para o português teve concordância quase perfeita para todos os domínios, excetuando-se o domínio Escola e Lazer cuja concordância foi considerada substancial. Palavras-chave: Pé; Tornozelo; Avaliação; Questionário.

The purpose of this study was to perform the translation and cross-cultural adaptation into Brazilian Portuguese of the Oxford Ankle Foot Questionnaire for children and teenagers. All internationally recommended steps for translation and cross-cultural validation of psychometric health instruments were followed. The translators were five pediatric orthopedic native speakers of Portuguese fluent in English; the backward translator was a native American English teacher fluent in Portuguese; the backward translation reviewers were three native American individuals with no health care expertise not fluent in Portuguese; the consultant was an individual competent in translation and validation of psychometric instruments native speaker of Portuguese and fluent in English. These individuals were responsible for the translation and backward translation of the questionnaire, whose versions were compared to the original in English. For cross-cultural adaptation, ten parents and children with flexible flat feet were used. The final Portuguese version had almost perfect agreement for all domains, except for the School and Leisure domain, whose agreement was considered substantial.

Keywords: Foot; Ankle; Assessment; Questionnaire. 


\section{Introduction}

Outcome measures of procedures based on the patient's own reports are increasingly frequent in clinical research and offer an opportunity to assess the individual's perspective on the clinical care offered. ${ }^{1}$ They are also able to reveal the impact that a given clinical condition has on the patient's health.

Most of the Patient Reported Outcome Measures (PROMs) developed for foot and ankle assessment are used for adults. ${ }^{2,3} \mathrm{Few}$ instruments have been developed for the pediatric population, most of which are specific and non-generic questionnaires, such as the juvenile rheumatoid arthritis juvenile arthritis foot disability index and the assessment of congenital clubfoot questionnaires. ${ }^{4,5}$ Specific instruments, however, are suitable for assessing a particular clinical condition and cannot be applied generally to all pathological conditions.

The Oxford Ankle Foot Questionnaire (OxAFQ) was developed in 2008, which is a generic PROM for assessing foot and ankle problems in pediatric patients. ${ }^{6-8}$ This questionnaire is the most commonly used instrument in orthopedic literature, with one version for the child and one for the parents; In addition, the OxAFQ allows to assess the dimensions: Physical activity, school and leisure, emotional, and footwear use.

The OxAFQ was originally developed in English and has already been translated into other languages; ${ }^{9} 10$ however it does not have a Brazilian Portuguese version yet. The Brazilian version will certainly contribute to a better understanding and analysis of children's foot and ankle problems, especially among pediatric orthopedics, physiotherapy and rheumatology professionals.

The study was approved by the Ethics Committee of Hospital Santa Izabel under Opinion No. 1.816.502.

\section{Material and Methods}

The study followed the ten steps for translation and cross-cultural adaptation proposed by ISPOR and AAOS. ${ }^{11}$ The steps were divided into initial translation, reconciliation, backward translation and pilot testing.

The team involved in the translation process was divided and classified as follows:

1. The first author was also project manager and key consultant;

2. The translators were five pediatric orthopedists native speakers of Portuguese fluent in English;

3. The independent translators were the five named pediatric orthopedists plus five medical students, five resident orthopedics and two individuals with experience in instrument translation, all native speakers of Portuguese fluent in English;

4. The backward translator was a Native American English teacher fluent in Portuguese who does not work with health care;

5. The reviewers of the backward translation were three Native American individuals with no health care expertise and also not fluent in Portuguese;

6. The consultant was an individual competent in translation and validation of psychometric instruments native speaker of Portuguese and fluent in English;

7. The final reviewer was a native speaker of Portuguese individual with academic background in linguistics.

The first two steps were preparation and translation. In this process, there was contact with the creator of the questionnaire to obtain information and study permission. Discussion and guidance were held with all staff involved in the process for clarification and certification of objectives. Finally, the first translation of the instrument into Portuguese (first version) was carried out.

The third step was reconciliation. This process was performed by the key consultant, translators and independent translators. The work was carried out as a panel of experts. The first (translators) were consulted to give suggestions on the initial translation and to model 
a second translation by consensus. Translators and independent translators, who did not participate in the initial translation, were consulted with the second version for agreement on the second version of the questionnaire. From the agreement results, modifications were always submitted to everybody's assessment, until the agreement obtained was considered acceptable (higher than 0.7 ), being the last version considered the conciliated translation.

The fourth step was the backward translation. In this process, the conciliated translation was forwarded to a translation professional (referred to here as backward translator), who prepared the backward translation into English. The review of the backward translation (fifth step) was carried out by three reviewers who assessed the backward translated questionnaire for agreement with the original questionnaire. Necessary modifications were made until the version was found to be in agreement. This process even included reviewing the conciliated translation and returning to previous steps if necessary. Step six (harmonization) was carried out exclusively by the key consultant who assessed the existing versions of the questionnaire for discrepancies that could be corrected.

Step seven was the cognitive assessment of the questionnaire. This process consisted of the application of the instrument version to the patient in a group of ten children, five boys and five girls, ranging from five to ten years old, with flexible flat feet. The parent's version was applied to the guardians of the children. The purpose of this process was to test agreement on understanding of the questions (items).

Step eight was the review of the cognitive assessment that was carried out by the key consultant, where any identified discrepancies could be corrected. The last two steps (final version revision and disclosure) were carried out by a reviewer (linguist) and key consultant.

\section{$\underline{\text { Statistical Analysis }}$}

Each version (translation and backward translation) was presented to its evaluators item by item with the proposition of classifying each item in three levels. The first level was called translation (or backward translation) and would be considered when the evaluator agreed that the item in both languages had the same meaning. The evaluator considered it acceptable (second level) when the item in both languages had similar meaning. Finally, the third level (inadequate) represented the situation in which the evaluator considered that there were semantic differences between the two translations. For the cognitive assessment, individuals were asked to answer if the questionnaire items were properly understood or if there was difficulty in understanding. From these level classifications, an interobserver kappa test was employed, using the value of 0.7 as the appropriate agreement.

\section{Results}

There was little difficulty in translating the instrument into Brazilian Portuguese (Tables 1 and 2). The largest disagreements were observed in questions seven, eight and nine. The backward translated version had better agreement with the original questionnaire than the Brazilian version. Individuals who ascertained cross-cultural adaptation were able to respond the instrument without difficulty on an average of $25 \mathrm{~min}$ for children and $17 \mathrm{~min}$ for parents.

Table 1 shows that the final Portuguese version had almost perfect agreement for all domains, except for the School and Leisure domain whose agreement was considered substantial. Yet the backward translated version obtained almost perfect agreement for all domains.

\section{Discussion}

The translation and cross-cultural adaptation of the "OXFORD ANKLE FOOT QUESTIONNAIRE - CHILD \& TEENAGER VERSION" into Brazilian Portuguese followed all the recommended steps for this type of study, ${ }^{11}$ resulting in a scientifically supported version. The 
Table 1. Agreement for the final versions of OxAFQ assessed by the reviewers: Brazilian Portuguese version and backward translated version into English.

\begin{tabular}{lcc}
\hline Domain & $\begin{array}{c}\text { Brazilian reviewers } \\
\text { (Forward translation) }\end{array}$ & $\begin{array}{c}\text { Foreign reviewers } \\
\text { (Backward translation) }\end{array}$ \\
\hline Physical (items 1 to 6) & 0.892 & 0.921 \\
School and leisure (items 7 to 10) & 0.789 & 0.831 \\
Emotional (items 11 to 14) & 0.845 & 0.935 \\
Footwear use (item 15) & 1 & 1 \\
\hline
\end{tabular}

Table 2. Intraclass correlation coefficient for the final version of OFAQ assessed by children and teenagers and parents.

\begin{tabular}{lcc}
\hline Domain & Children's version & Parents' version \\
\hline Physical (items 1 to 6) & 0.920 & 0.931 \\
School and leisure (items 7 to 10) & 0.886 & 0.892 \\
Emotional (items 11 to 14) & 0.931 & 0.954 \\
Footwear use (item 15) & 1 & 1 \\
\hline
\end{tabular}

translation also presented agreement results that attest to the quality achieved. From now on, this version may be used by Brazilian researchers with the technical-scientific guarantee of an instrument with appropriate cross-cultural translation and validation. In addition, the version presented was authorized and approved by the developers of the original instrument, thus becoming the only official version in Brazilian Portuguese.

There is a fundamental importance of the Brazilian Portuguese version of "OXFORD ANKLE FOOT QUESTIONNAIRE - CHILD \& TEENAGER VERSION" for the national scientific community and especially for physiotherapists, foot specialized orthopedists or pediatric orthopedists. This questionnaire is a single generic instrument for assessment of feet and ankles of children and teenagers that allows comparison between several different clinical conditions. Like any PROM, it can be used to assess patients' perceptions of their health condition and treatment outcomes. ${ }^{1}$

There are currently several psychometric measures for foot and ankle assessment in adult patients $^{2,3}$ or instruments used for children with specific diseases. ${ }^{4,5}$ Many of these instruments have already been translated or are being used in the Brazilian Portuguese. The Oxford Ankle Foot Questionnaire - child and teenager version - is the most appropriate and widespread instrument for this purpose with children. ${ }^{6-8}$ Cross-cultural translation and adaptation for the Brazilian public will result in the provision of an appropriate PROM to raise the level of national research in this area.

OxAFQ versions in Danish, Dutch and Italian already exist.9-12 The Italian version has been tested on patients with flexible flat feet; The Danish version has been assessed in patients with various foot problems; while the Dutch version was tested on patients with surgical foot problems. Regarding validity, all versions ranged from 0.53 to 0.99 .

Our study provided a Brazilian version of the OxAFQ, obtained by internationally accepted criteria for translation and cross-cultural validation of psychometric instruments. The Brazilian version 
was tested with a group of parents and patients who responded in a period of time considered satisfactory and with comprehension assessed as adequate. Our version of the OxAFQ, however, will still need to be tested with a larger group of children and teenagers to assess its validity in terms of accuracy and reproducibility.

\section{References}

1. Black N. Patient reported outcome measures could help transform healthcare. BMJ. 2013;346:f167.

2. Hunt KJ, Hurwit D. Use of patient-reported outcome measures in foot and ankle research. J Bone Joint Surg Am. 2013;95:e118(1-9).

3. Riskowski JL, Hagedorn TJ, Hannan MT. Measures of foot function, foot health, and foot pain: American Academy of Orthopedic Surgeons Lower Limb Outcomes Assessment: Foot and Ankle Module (AAOSFAM), Bristol Foot Score (BFS), Revised Foot Function Index (FFI-R), Foot Health Status Questionnaire (FHSQ), Manchester Foot Pain and Disability Index (MFPDI), Podiatric Health Questionnaire (PHQ), and Rowan Foot Pain Assessment (ROFPAQ). Arthritis Care Res (Hoboken). 2011;63(Suppl. 11):S229.

4. André M, Hagelberg S, Stenström CH. The juvenile arthritis foot disability index: development and evaluation of measurement properties. J Rheumatol. 2004;31:2488-93.

5. Roye BD, Vitale MG, Gelijns AC, Roye DP Jr. Patientbased outcomes after clubfoot surgery. J Pediatr Orthop. 2001;21:42-9.
6. Morris C, Doll HA, Wainwright A, Theologis T, Fitzpatrick R. The Oxford ankle foot questionnaire for children: scaling, reliability and validity. J Bone Joint Surg Br. 2008;90:1451.

7. Morris C, Doll H, Davies N, Wainwright A, Theologis $\mathrm{T}$, Willett $\mathrm{K}$, et al. The Oxford ankle foot questionnaire for children: responsiveness and longitudinal validity. Qual Life Res. 2009;18:1367.

8. Morris C, Doll H, Wainwright A, Davies N, Theologis T, Fitzpatrick R. The Oxford ankle foot questionnaire for children: review of development and potential applications. Prosthet Orthot Int. 2010;34:238.

9. Burger E, Selles R, Nieuwkasteele S, Bessems G, Pollet $\mathrm{V}$, Hovius S, Nieuwenhoven C. The Dutch version of the Oxford Ankle and Foot Questionnaire for Children: Useful for evaluation of pediatric foot problems in groups. Foot Ankle Surg. 2019;25(2):204-210.

10. Martinelli N, Romeo G, Bonifacini C, Viganò M, Bianchi A, Malerba F. Validation of the Italian version of the Oxford Ankle Foot Questionnaire for children. Qual Life Res. 2016;25(1):117-23.

11. Wild D, Grove A, Martin M, Eremenco S, McElroy S, Verjee-Lorenz A, Erikson P. Principles of Good Practice for the Translation and Cultural Adaptation Process for Patient-Reported Outcomes (PRO) Measures: Report of the ISPOR Task Force for Translation and Cultural Adaptation. Value Health. 2005 8(2):94-104.

12. Martinkevich P, Møller-Madsen B, Gottliebsen M, Kjeldgaard L, Rahbek O. Validation of the translated Oxford ankle foot questionnaire in 82 Danish children aged between five and 16 years. Bone Joint J. 2005;97-B(3):420-6.

\section{ANNEX \\ OXFORD ANKLE FOOT QUESTIONNAIRE - CHILD \& TEENAGER VERSION}

The questions below are based upon ways in which some young people told us they had been affected by a foot or ankle problem.

We want you to think about each question and then put a tick or a cross next to the answer that best describes you - was it never a problem for you, or was it always a problem for you, or somewhere in between?

Thinking about the last two weeks..

1. Have you found walking difficult because of your foot or ankle?

$\begin{array}{ccccc}\text { never } & \text { rarely } & \text { sometimes } & \text { very often } & \text { always } \\ 0 & 0 & 0 & 0 & 0\end{array}$


2. Have you found it difficult to run because of your foot or ankle?

$\begin{array}{ccccc}\text { never } & \text { rarely } & \text { sometimes } & \text { very often } & \text { always } \\ 0 & 0 & 0 & 0 & 0\end{array}$

3. Has it been difficult to stand up for long periods?

$\begin{array}{ccccc}\text { never } & \text { rarely } & \text { sometimes } & \text { very often } & \text { always } \\ 0 & 0 & 0 & 0 & 0\end{array}$

4. Have you had pain in your foot or ankle?

$\begin{array}{ccccc}\text { never } & \text { rarely } & \text { sometimes } & \text { very often } & \text { always } \\ 0 & 0 & 0 & 0 & 0\end{array}$

5. Have your legs been sore or ached after walking or running?

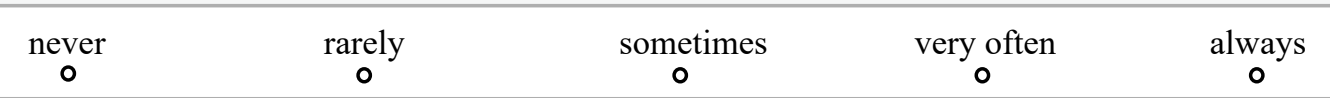

6. Have you felt tired because of your foot or ankle?

$\begin{array}{ccccc}\text { never } & \text { rarely } & \text { sometimes } & \text { very often } & \text { always } \\ 0 & 0 & 0 & 0 & 0\end{array}$

7. Has your foot or ankle stopped you joining in with others in the playground?

$\begin{array}{ccccc}\text { never } & \text { rarely } & \text { sometimes } & \text { very often } & \text { always } \\ 0 & 0 & 0 & 0 & 0\end{array}$

8. Has your foot or ankle stopped you playing in the park or outside?

$\begin{array}{llll}\text { never } & \text { rarely } & \text { sometimes } & \text { veryoften }\end{array}$

9. Has your foot or ankle stopped you taking part in PE lessons?

\begin{tabular}{|c|c|c|c|}
\hline never & $\underset{0}{\text { rarely }}$ & $\underset{0}{\text { sometimes }}$ & very often \\
\hline
\end{tabular}

10. Has your foot or ankle stopped you taking part in any other lessons at school?

\begin{tabular}{|c|c|c|}
\hline $\begin{array}{c}\text { never } \\
\text { o }\end{array}$ & $\begin{array}{c}\text { rarely } \\
0\end{array}$ & $\underset{0}{\text { sometimes }}$ \\
\hline
\end{tabular}

11. Have you been bothered by how your foot or ankle looks?

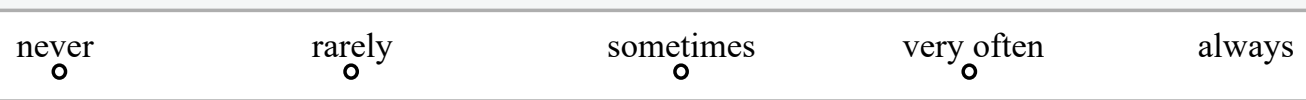

12. Has the way you walk bothered you?

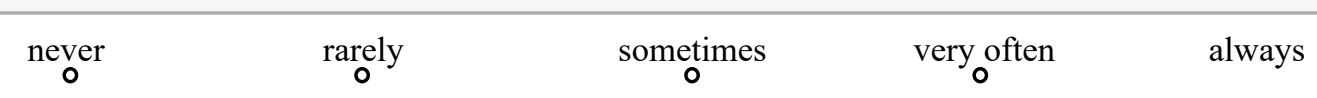

13. Have you been embarrassed because of your foot or ankle?

$\begin{array}{cccc}\text { never } & \text { rarely } & \text { sometimes } & 0 \\ 0 & \text { very often } & \text { always }\end{array}$

14. Has anyone been unkind to you because of your foot or ankle?

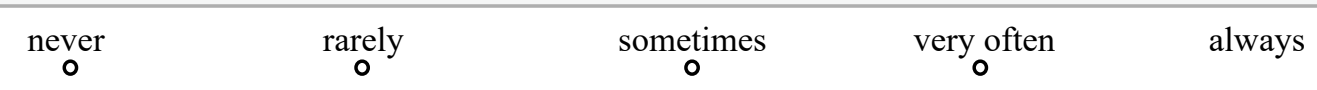

15. Has your foot or ankle stopped you wearing any shoes you wanted to wear?

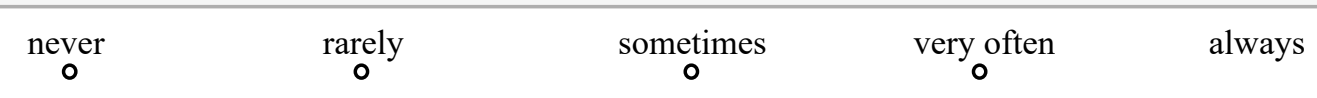




\section{OXFORD ANKLE FOOT QUESTIONNAIRE - PARENT VERSION}

The questions below are based upon ways in which some young people told us they had been affected by a foot or ankle problem.

We want you to think about each question and then put a tick or a cross next to the answer that best describes your child - was it never a problem for them, or was it always a problem, or was it somewhere in between?

Thinking about the last week...

16. Has your child found walking difficult because of their foot or ankle?

\begin{tabular}{|c|c|}
\hline $\begin{array}{c}\text { never } \\
\text { o }\end{array}$ & rarely \\
\hline
\end{tabular}

17. Has your child found it difficult to run because of their foot or ankle?

\begin{tabular}{|c|c|c|c|}
\hline never & rarely & sometimes & \\
\hline
\end{tabular}

18. Has it been difficult for your child to stand up for long periods?

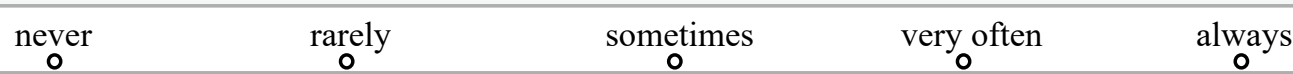

19. Has your child had pain in their foot or ankle?

\begin{tabular}{|c|c|c|c|}
\hline never & $\underset{0}{\text { rarely }}$ & sometimes & very often \\
\hline
\end{tabular}

20. Have your child's legs been sore or ached after walking or running?

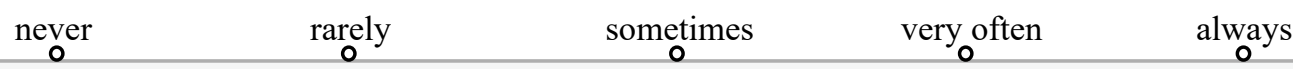

21 . Has your child felt tired because of their foot or ankle?

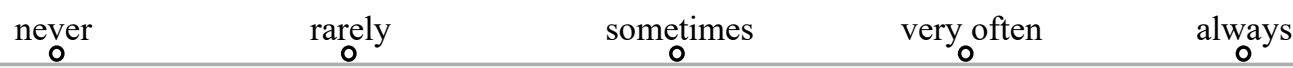

22. Has your child's foot or ankle stopped them joining in with others in the playground?

\begin{tabular}{|c|c|c|c|}
\hline never & rarely & sometimes & very often \\
\hline
\end{tabular}

23. Has your child's foot or ankle stopped them playing in the park or outside?

never rarely $\quad$ somedimes veryoften always

24. Has your child's foot or ankle stopped them taking part in PE lessons?

never rarely sometimes very often always

25. Has your child's foot or ankle stopped them taking part in any other lessons at school?

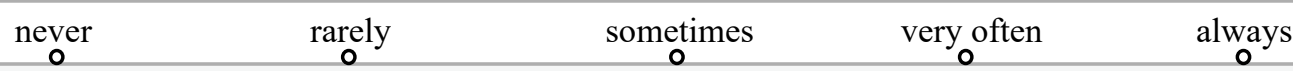

26. Has your child been bothered by how their foot or ankle looks?

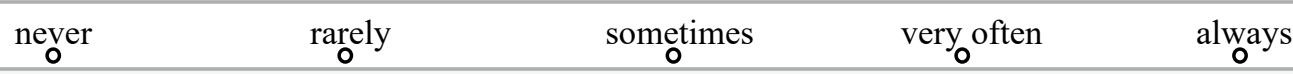

27. Has the way your child walks bothered them?

\begin{tabular}{|c|c|c|c|}
\hline never & $\underset{0}{\text { rarely }}$ & sometimes & very often \\
\hline
\end{tabular}

28. Has your child been embarrassed because of their foot or ankle?

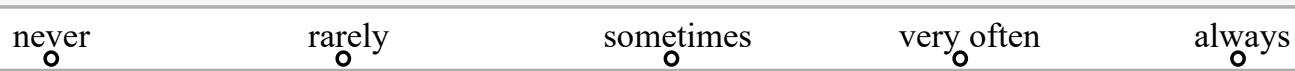

29. Has anyone been unkind to your child because of their foot or ankle?

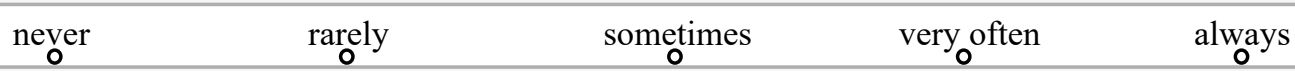

30. Has your child's foot or ankle stopped them wearing any shoes they wanted to wear?

$\begin{array}{ccccc}\text { never } & \text { rarely } & \text { sometimes } & \text { very often } & \text { always } \\ 0 & 0 & 0 & 0 & 0\end{array}$




\section{Brazilian version of the "OXFORD ANKLE FOOT QUESTIONNAIRE - CHILD AND TEENAGER VERSION" \\ QUESTIONÁRIO OXFORD PARA PÉ E TORNOZELO - VERSÃO INFANTIL E ADOLESCENTE}

As questões abaixo são baseadas na forma como algumas pessoas jovens nos contam como são afetadas por um problema no pé ou tornozelo.

Nós queremos que você pense a respeito de cada questão e então marque a resposta que melhor descreve você - isto nunca foi um problema para você ou isto sempre foi um problema para você ou ainda se de alguma forma é um problema intermediário?

Pensando sobre a última semana...

1. Você acha difícil andar por causa do seu pé ou tornozelo?
$\square$ Nunca
$\square$ Raramente
$\square$ Algumas vezes
$\square$ Frequentemente
$\square$ Sempre

2. Você acha difícil correr por causa do seu pé ou tornozelo?

$\square$ Nunca $\quad \square$ Raramente $\quad \square$ Algumas vezes $\quad \square$ Frequentemente $\quad \square$ Sempre

3. Tem sido difícil ficar em pé por tempo prolongado?

$\square$ Nunca $\quad \square$ Raramente $\quad \square$ Algumas vezes $\quad \square$ Frequentemente $\quad \square$ Sempre

4. Você sente dor no seu pé ou no seu tornozelo?

$\square$ Nunca $\quad \square$ Raramente $\quad \square$ Algumas vezes $\quad \square$ Frequentemente $\quad \square$ Sempre

5. Suas pernas ficam sensíveis ou doloridas depois de andar ou correr?
$\square$ Nunca
$\square$ Raramente
$\square$ Algumas vezes
$\square$ Frequentemente
$\square$ Sempre

6. Você se sente cansado por causa do seu pé ou tornozelo?
$\square$ Nunca
$\square$ Raramente
$\square$ Algumas vezes
$\square$ Frequentemente
$\square$ Sempre

7. Seu pé ou tornozelo impede você de se reunir com outros no playground (varanda ou quintal)?
$\square$ Nunca
$\square$ Raramente
$\square$ Algumas vezes
$\square$ Frequentemente
$\square$ Sempre

8. Seu pé ou tornozelo impede você de brincar no parque ou fora de casa?
$\square$ Nunca
$\square$ Raramente
$\square$ Algumas vezes
$\square$ Frequentemente
$\square$ Sempre

9. Seu pé ou tornozelo fazem você parar de participar de aulas de educação física?
$\square$ Nunca
$\square$ Raramente
$\square$ Algumas vezes
$\square$ Frequentemente
$\square$ Sempre

10. Seu pé ou tornozelo impede você de participar de qualquer outra aula na escola?
$\square$ Nunca
$\square$ Raramente
$\square$ Algumas vezes
$\square$ Frequentemente
$\square$ Sempre 
11. Você se sente incomodado com a aparência do seu pé ou tornozelo?
$\square$ Nunca
$\square$ Raramente
$\square$ Algumas vezes
$\square$ Frequentemente
$\square$ Sempre

12. Você se incomoda com a maneira como você anda?
$\square$ Nunca
$\square$ Raramente
$\square$ Algumas vezes
$\square$ Frequentemente
$\square$ Sempre

13. Você se sente envergonhado por causa do seu pé ou tornozelo?
$\square$ Nunca
$\square$ Raramente
$\square$ Algumas vezes
$\square$ Frequentemente
$\square$ Sempre

14. Alguém trata você mal por causa do seu pé ou tornozelo?
$\square$ Nunca
$\square$ Raramente
$\square$ Algumas vezes
$\square$ Frequentemente
$\square$ Sempre

15. Seu pé ou tornozelo impede você de calçar algum sapato que você deseje usar?
$\square$ Nunca
$\square$ Raramente
$\square$ Algumas vezes
$\square$ Frequentemente
$\square$ Sempre

\section{QUESTIONÁRIO OXFORD PARA PÉ E TORNOZELO - VERSÃO DOS PAIS}

As questões abaixo são baseadas na forma como algumas pessoas jovens nos contam como são afetadas por um problema no pé ou tornozelo.

Nós queremos que você pense a respeito de cada questão e então marque a resposta que melhor descreve seu filho isto nunca foi um problema para ele ou isto sempre foi um problema para ele ou ainda se de alguma forma é um problema intermediário?

Pensando sobre a última semana...

16. Seu filho acha difícil andar por causa do pé ou tornozelo?

$\square$ Nunca $\quad \square$ Raramente $\quad \square$ Algumas vezes $\quad \square$ Frequentemente $\quad \square$ Sempre

17. Seu filho acha difícil correr por causa do pé ou tornozelo?
$\square$ Nunca
$\square$ Raramente
$\square$ Algumas vezes
$\square$ Frequentemente
$\square$ Sempre

18. Tem sido difícil para seu filho ficar em pé por tempo prolongado?
$\square$ Nunca
$\square$ Raramente
$\square$ Algumas vezes
$\square$ Frequentemente
$\square$ Sempre

19. Seu filho sente dor no pé ou tornozelo?
$\square$ Nunca
$\square$ Raramente
$\square$ Algumas vezes
$\square$ Frequentemente
$\square$ Sempre

20. As pernas do seu filho ficam sensíveis ou doloridas depois de andar ou correr?
$\square$ Nunca
$\square$ Raramente
$\square$ Algumas vezes
$\square$ Frequentemente
$\square$ Sempre 
21. Seu filho se sente cansado por causa do pé ou tornozelo?
$\square$ Nunca $\square$ Raramente
$\square$ Algumas vezes
$\square$ Frequentemente
$\square$ Sempre

22. O pé ou tornozelo do seu filho impede ele de se reunir com outros no playground (varanda, pátio ou quintal)?
$\square$ Nunca
$\square$ Raramente
$\square$ Algumas vezes
$\square$ Frequentemente
$\square$ Sempre

23. O pé ou tornozelo do seu filho impede ele de brincar no parque ou fora de casa?
$\square$ Nunca
$\square$ Raramente
$\square$ Algumas vezes
$\square$ Frequentemente
$\square$ Sempre

24. O pé ou tornozelo do seu filho faz ele parar de participar de aulas de educação física?
$\square$ Nunca
$\square$ Raramente
$\square$ Algumas vezes
$\square$ Frequentemente
$\square$ Sempre

25. O pé ou tornozelo do seu filho impede ele de participar de qualquer outra aula na escola?
$\square$ Nunca
$\square$ Raramente
$\square$ Algumas vezes
$\square$ Frequentemente
$\square$ Sempre

26. Seu filho se sente incomodado com a aparência do pé ou tornozelo?

$\square$ Nunca $\quad \square$ Raramente $\quad \square$ Algumas vezes $\quad \square$ Frequentemente $\quad \square$ Sempre

27. Seu filho se incomoda com a maneira que ele anda?

$\square$ Nunca $\quad \square$ Raramente $\quad \square$ Algumas vezes $\quad \square$ Frequentemente $\quad \square$ Sempre

28. Seu filho se sente envergonhado por causa do pé ou tornozelo?

$\square$ Nunca $\quad \square$ Raramente $\quad \square$ Algumas vezes $\quad \square$ Frequentemente $\quad \square$ Sempre

29. Alguém trata seu filho mal por causa do pé ou tornozelo?
$\square$ Nunca
$\square$ Raramente
$\square$ Algumas vezes
$\square$ Frequentemente
$\square$ Sempre

30. O pé ou tornozelo do seu filho impede ele de calçar algum sapato que ele deseje usar?

$\square$ Nunca $\quad \square$ Raramente $\quad \square$ Algumas vezes $\quad \square$ Frequentemente $\quad \square$ Sempre 